\title{
Transport of Owenia fusiformis larvae (Annelida: Polychaeta) in the Bay of Seine. I. Vertical distribution in relation to water column stratification and ontogenic vertical migration*
}

\author{
Eric Thiébaut ${ }^{1}$, Jean-Claude Dauvin ${ }^{2}$, Yvan Lagadeuc ${ }^{3, * *}$ \\ ${ }^{1}$ Observatoire Océanologique de Roscoff, Station biologique, BP 74, F-29682 Roscoff Cedex, France \\ ${ }^{2}$ Muséum National d'Histoire Naturelle, Laboratoire de Biologie des Invertébrés Marins et Malacologie, 57 rue Cuvier, \\ F-75231 Paris Cedex 05, France \\ ${ }^{3}$ Université des Sciences et Techniques de Lille, Station marine, BP 80, F-62930 Wimereux, France
}

\begin{abstract}
The vertical distribution of Owenia fusiformis larvae was studied from pump samples in the eastern part of the Bay of Seine, English Channel, between 9 May and 9 June 1987. Only 1 massive larval cohort was present. Four planktonic stages of different duration were distinguished. The duration of total larval life was estimated to be about 1 mo. Larvae were located preferentially under the pycnocline. Larvae showed an ontogenic migration with an increase of the larval center of mass (ZCM) for each stage according to age. This migration was associated with the 2-layer circulation present in the study area. Stage 1 was principally present in the diluted surface layer and carried downstream. Stage 2 was located just above the depth where the seaward residual flow is null. Downstream transport of these larvae should have been limited. Stages 3 \& 4 were located below the level of no net motion and consequently were transported upstream. However, the vertical distribution of Stages $1 \& 2$ could be changed in relation to water column stratification. When the stratification was stight, these larvae were evenly distributed over the water column, whereas a strong stratification generated a larval concentration under the pycnocline. The depth of larvae in the water may have resulted from interactions between behavior and water column structure. Ontogenic migration and aggregation of Stage 2 larvae just above the depth where net residual flow is null played a basic role in larval retention in the eastern part of the Bay of Seine and should partly explain the spatio-temporal stability of the adults.
\end{abstract}

\section{INTRODUCTION}

The knowledge of processes controlling invertebrate larvae transport in estuaries and coastal waters is fundamental to the interpretation of population biology, distribution of adults and their spatio-temporal stability, and population genetics. Recently, research concerning larval dispersal capabilities (e.g. Scheltema 1986, Stancyk \& Feller 1986, Epifanio et al. 1989) and mechanisms of retention (De Wolf 1974, Cronin 1982, Cronin \& Forward 1986) has been conducted. Vertical

- Contribution to the PNDR (Programme National sur le Déterminisme du Recrutement) under the program 'GDR Manche

- Present address: GIROQ, Département de Biologie, Université Laval, Ste-Foy, Québec, Canada G1K 7 P4 distribution played a major role in horizontal transport (Cameron 1986). Larval vertical distribution may result from (1) passive transport of larvae by mechanical processes alone (De Wolf 1974, Banse 1986, Levin 1986 ) or (2) active larval ability to regulate their position in the water column (Sulkin 1984, Cronin \& Forward 1986, Cameron 1986).

The English Channel, an epicontinental and megatidal sea, is characterized by confinement of fine sediments to shallow waters of bays and estuaries (Cabioch et al. 1982). These conditions are found in the Bay of Seine, English Channel, (Cabioch \& Gentil 1975, Gentil 1976) and are favourable for studying the role of hydrodynamic processes in larval dispersion and/or the retention of macrobenthic species living in these isolated communities. These conditions provide an indication of the larval input, the possibility to follow larvae in 


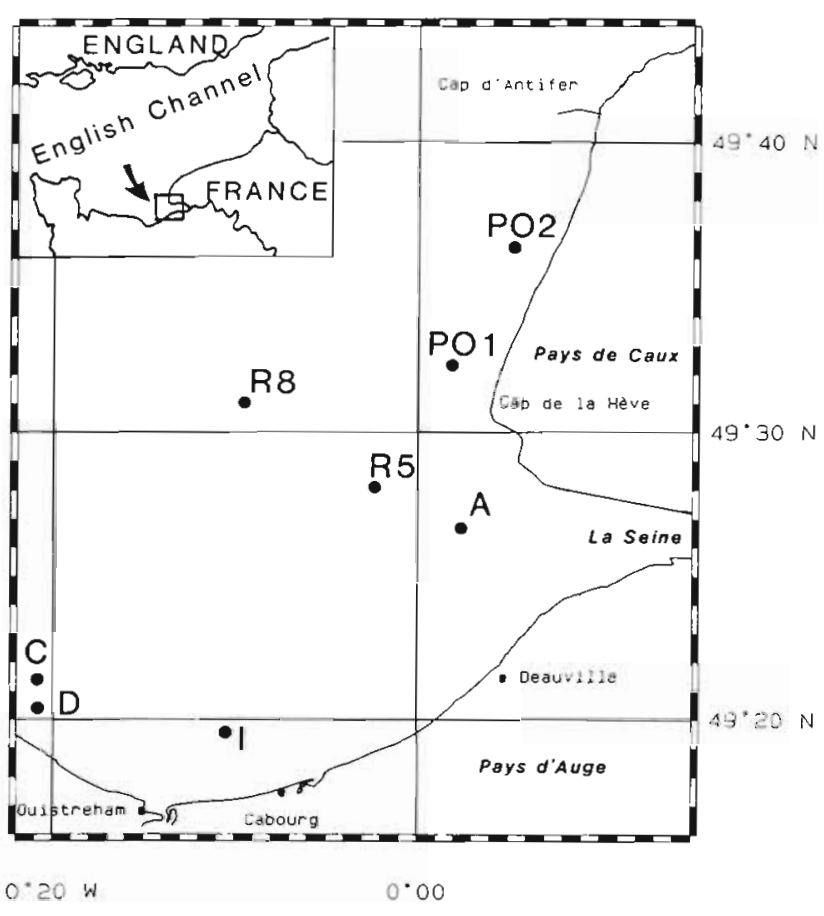

Fig. 1. Study area and location of sampling stations in the eastern part of Bay of Seine (English Channel)

water masses, and the capacity to estimate postlarval recruitment and larval loss from the population.

The Bay of Seine is a quadrilateral embayment, ca 65 by $140 \mathrm{~km}$ wide and 10 to $30 \mathrm{~m}$ deep. The general hydrodynamic conditions in the Bay are well known (see Cabioch 1986 for a detailed description). Residual circulation depends on 3 factors: (1) tide, (2) horizontal gradients of density due to the Seine and (3) meteorological factors, especially wind (Le Hir et al. 1986). The maximal tidal range in the eastern part of the Bay of Seine is $7.50 \mathrm{~m}$ and the instantaneous tidal circulation varies between 0.5 and $0.8 \mathrm{~m} \mathrm{~s}^{-1}$ (Chabert d'Hières 1986). Because of horizontal density gradients, the eastern part of the Bay of Seine acts as a partially mixed estuary with a 2-layer circulation. The diluted surface layer is characterized by a net seaward flow and the deeper saline layer exhibits landward residual flow (Salomon 1986).

The tubicolous polychaete Owenia fusiformis Delle Chiaje is one of the most common species in the Abra alba-Pectinaria koreni community on isolated muddy fine sand off the eastern Bay of Seine (Gentil et al. 1986). It forms 3 main patches of abundance: (1) along the Pays de Caux (see Fig. 1), (2) just seaward off the Seine estuary and (3) along the Pays d'Auge. These patches are stable in time and space (Dauvin \& Gillet 1991). O. fusiformis was chosen to study the interactions between physical processes and recruitment because of its abundance, time-limited reproduction in spring (Gentil et al. 1990), pelagic larval life of about 1 mo (Wilson 1932) and easily identified mitraria larvae.

The objectives of this project were to examine the vertical distribution of Owenia fusiformis larvae, the presence of an ontogenic migration and relationships between this distribution and the water column stratification. The impact of larval vertical distribution on larval transport and recruitment in the Bay of Seine is discussed in relation to hydrodynamics, especially the 2-layer circulation.

\section{MATERIALS AND METHODS}

Sampling. Stations I (mean depth: $14 \mathrm{~m}), \mathrm{D}(12 \mathrm{~m})$ \& $\mathrm{C}(13 \mathrm{~m})$ located along the coasts of the Pays d'Auge (Fig. 1) were sampled on 9 May 1987, and $S t n \mathrm{PO}_{1}$ $(17 \mathrm{~m}) \& \mathrm{PO}_{2}(25 \mathrm{~m})$ along the coasts of the Pays de Caux in the plume of the estuary were sampled on 16 May 1987. Three additional stations (Fig. 1) along a gradient of the Seine estuary, $\operatorname{Stn} A(14 \mathrm{~m}), R_{5}(15 \mathrm{~m})$ \& $\mathrm{R}_{8}(22 \mathrm{~m})$, were sampled between 16 May and 3 June 1987 every 2 or $4 \mathrm{~d}$ when Owenia fusiformis larvae were at their peak abundance. Final sampling was conducted on 9 June at Stns $A, R_{5} \& R_{8}$. Considering larval life duration, this sampling frequency allowed us to determine the temporal evolution of larval vertical distribution in relation to their age.

Samples were taken at $2 \mathrm{~m}$ intervals, starting at $1 \mathrm{~m}$ below the water surface, using a PCM Moineau pump and a $10 \mathrm{~cm}$ diam. collection pipe. The volumetric pump had 2 helicoidal gearings and delivered a constant flow of $300 \mathrm{l} \mathrm{min}^{-1}$. A sample of $0.6 \mathrm{~m}^{3}$ seawater was obtained from each depth in $2 \mathrm{~min}$ and filtered through an $80 \mu \mathrm{m}$ mesh net. Before sampling, salinity and temperature were measured to characterize the water column structure for each station, except at Stns I, D \& C on 9 May. In this first study, sampling was only conducted during daylight as no diel vertical migration was previously observed in polychaete larvae. Tidal ranges during the surveys varied between $4.10 \mathrm{~m}$ on 3 June 1987 and $6.75 \mathrm{~m}$ on 16 May 1987.

All samples were preserved in $5 \%$ formalin buffered with sodium borate. Larval counts were obtained using the Frontier method (1969, 1972): the sample was brought to $200 \mathrm{ml}$ with seawater, homogenised, and a $1 / 10$ aliquot was pipetted into a reticulated Dolfuss receptacle composed of 200 distinct cells. Planktonic organisms were randomly distributed in the receptacle. Approximately 100 larvae were counted per sample to obtain a good estimate of larval abundances (Frontier 1972). Results were expressed as number of larvae $\mathrm{m}^{-3}$.

Owenia fusiformis larval stages. From the larval 
development description (Wilson 1932), 4 planktonic stages are distinguished. Stage 1 is a trochosphere which is 1 to $6 \mathrm{~d}$ old, 150 to $200 \mu \mathrm{m}$ in length, with a prototroch in normal extension (not arched) and 2 to 8 bristles. Stage 2 is 6 to $21 \mathrm{~d}$ old and measures 200 to $550 \mu \mathrm{m}$. The prototroch is arched in front, behind and at the sides, and the overall number of bristles is greater than in Stage 1. Stage 3 is 21 to $28 \mathrm{~d}$ old and its length reaches $710 \mu \mathrm{m}$. The trunk rudiment of the worm is visible dorsally. Stage 4 is the planktonic postlarvae. Its planktonic life duration is short, about 1 or $2 \mathrm{~d}$.

Data analysis. To reflect the mean depth of Owenia fusiformis larvae for each profile, the center of mass of the distribution (ZCM) was calculated as in Fortier \& Leggett (1982):

$$
\mathrm{ZCM}=\sum_{i=1}^{n} p_{i} \cdot z_{i}
$$

where $p_{1}=$ proportion of the total number of larvae in the $i$ th depth interval; and $z_{1}=$ mean depth of the $i$ th interval. To measure larval aggregation, the coefficient of variation ( $\mathrm{CV}$ : standard deviation/mean) of larval concentration in the different intervals was used. A high $\mathrm{CV}$ indicated a strong aggregation of larvae and conversely, a low CV indicated a more homogeneous distribution of larvae in the water column.

An index of water column stratification $(\hat{S})$ was calculated as follows (Fortier \& Leggett 1982):

$$
\hat{S}=\frac{1}{n} \sum_{i=1}^{n} \Delta \sigma_{t_{i}} \Delta z_{i}
$$
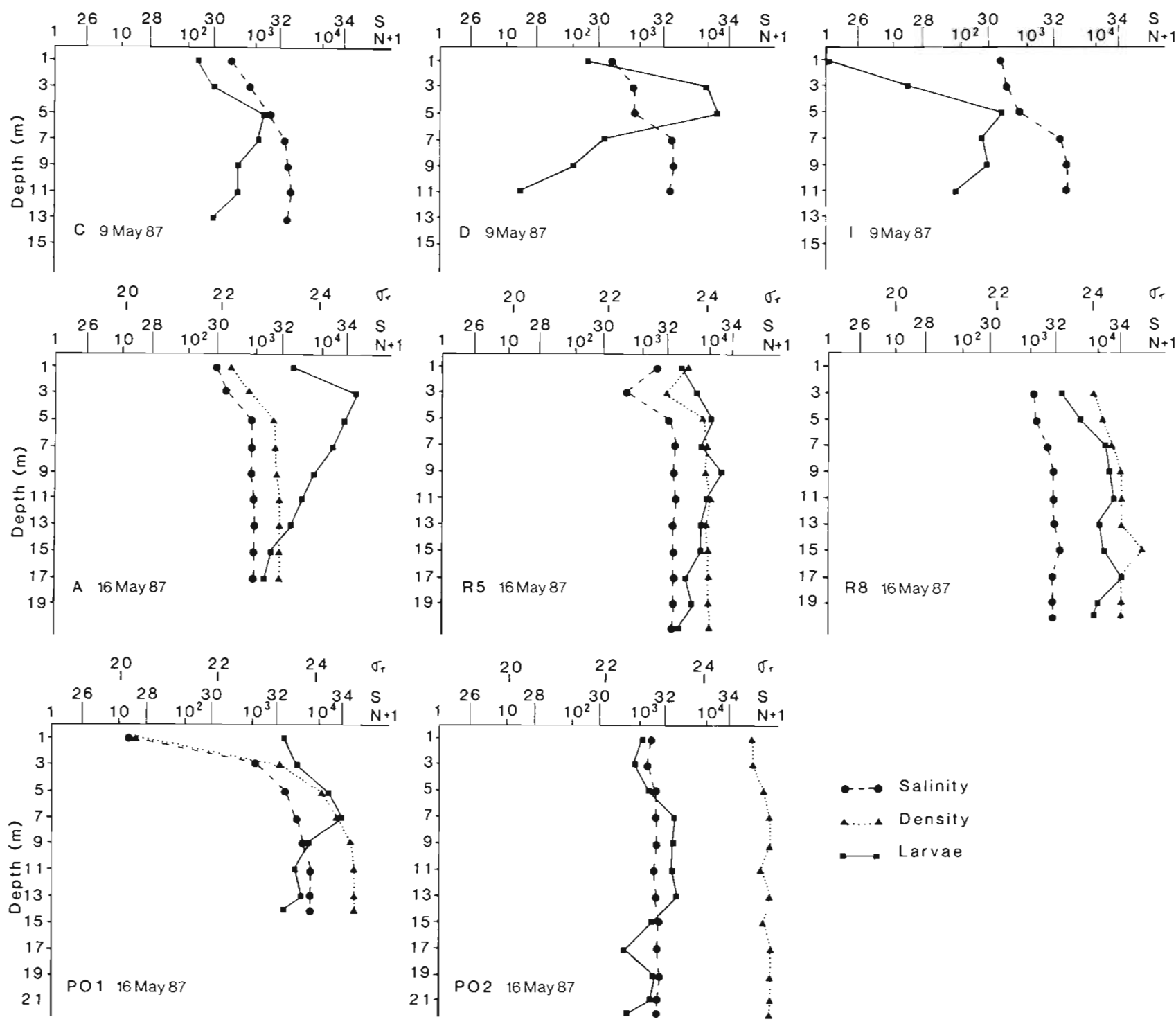

Fig. 2. Owenia fusiformis. Profiles of salinity $(\mathrm{S})$, density $\left(\sigma_{T}\right)$ and larval concentration $\left(\mathrm{m}^{-3}\right)(\mathrm{N}+1)$ at $\mathrm{Stns} \mathrm{C}, \mathrm{D} \& \mathrm{I}(9 \mathrm{May} 1987)$ and at Stns $A, R_{5}, R_{8}, P O_{1} \& \mathrm{PO}_{2}$ (16 May 1987) 

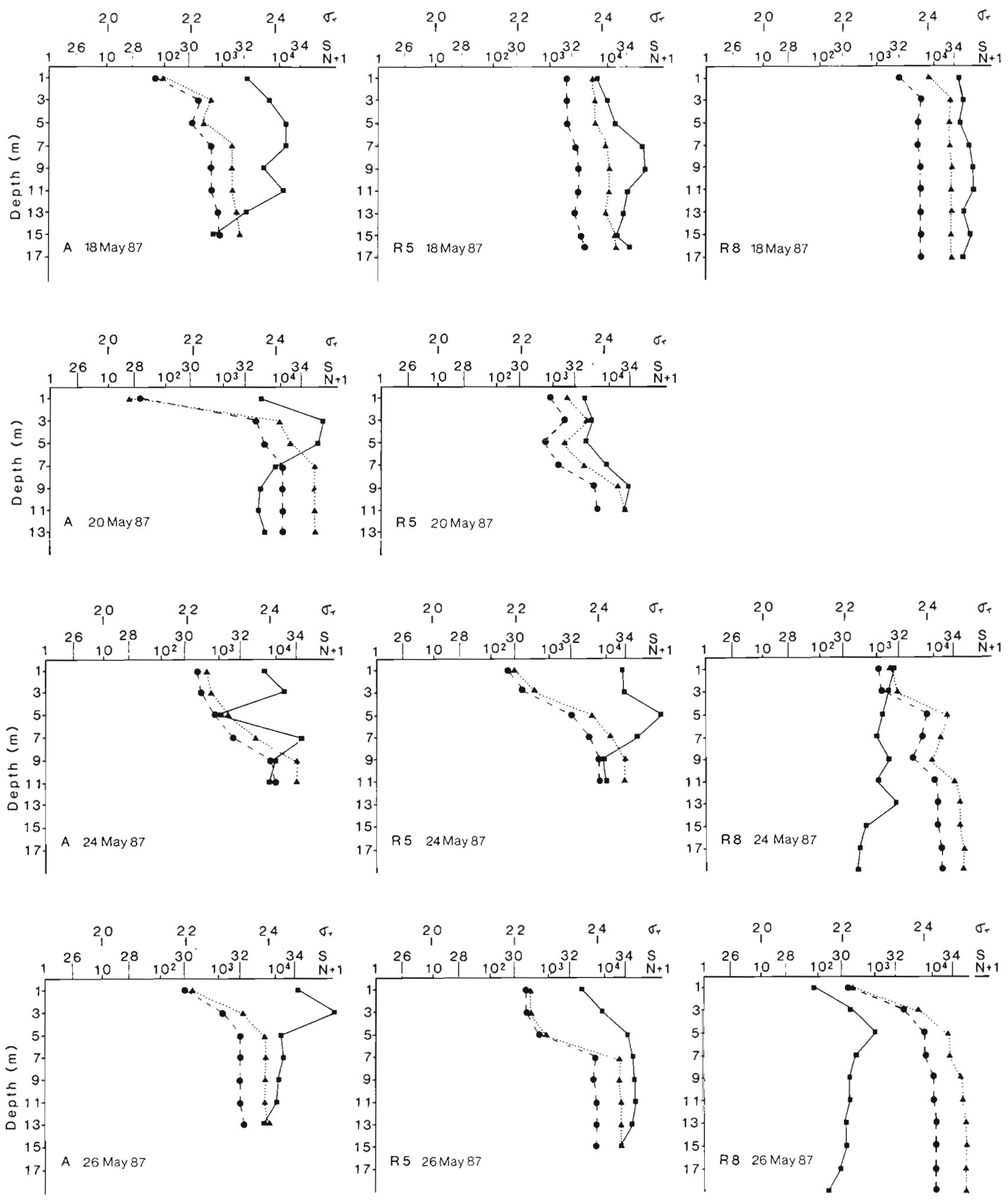

$\leftrightarrow$ Salinity

A....... Density

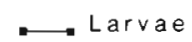

Fig. 3. Owenia fusiformis. Profiles of salinity (S), density $\left(\sigma_{\Upsilon}\right)$ and larval concentration $\left(m^{-3}\right)(N+1)$, at $S t n s A_{1} R_{5} \& R_{8}(18,20,24 \&$ 26 May 1987 
where $\mathrm{n}=$ number of pairs of adjacent measurements; $\Delta \sigma_{t}=$ difference in sigma- $t$ between the ith pair of measurements; and $\Delta z_{1}=$ depth interval between the pair of measurements. Pycnocline depth was estimated as the center of the sampling interval where the change in sigma-t was maximal. The depth where the seaward longitudinal residual flow generated by horizontal density gradients is null $\left(z_{u=0}\right)$ was estimated by solving the equation (Salomon 1986):

$$
u=\frac{1}{48} \frac{g}{p} \frac{\delta p}{\delta x} \frac{h^{3}}{N}\left(8 n^{3}-9 n^{2}+1\right) \text { where } n=1-\frac{z}{h}
$$

and $u=$ seaward residual flow; $g=$ gravity; $p=$ density; $h=$ height of the water column; $N=$ coefficient of vertical turbulent viscosity; and $z=$ depth. $O-x$ is an axis in the direction of the estuary. The values of $g, \delta p / \delta x$ and $N$ were, respectively, $9.81 \mathrm{~m} \mathrm{~s}^{-2}$, $2 \times 10^{-4} \mathrm{~m}^{-1}$ and $10^{-2} \mathrm{~m}^{2} \mathrm{~s}^{-1}$. This equation gives an analytical estimation of the residual circulation generated by density gradients. Simplified from general equations of hydrodynamics, it considers the critical conditions of a null velocity near the bottom. Coriolis force on the $O-X$ axis is neglected as it is small in relation to pressure and viscosity forces.

\section{RESULTS}

\section{Physical data}

The eastern part of the Bay of Seine was characterized as a partially well-mixed estuary. At all stations, the water column was more or less stratified with vertical gradients of temperature, salinity and density (Figs. 2, $3 \& 4$ ). Density structure was primarily a function of the salinity structure. Stratification decreased in a downstream direction from Stn A to Stn $\mathrm{R}_{8}$ (Table 1). Stratification was maximal at $\mathrm{Stn} \mathrm{PO}_{1}$ along the Pays de Caux in relation to its localisation in the plume of the estuary; the gradients between the

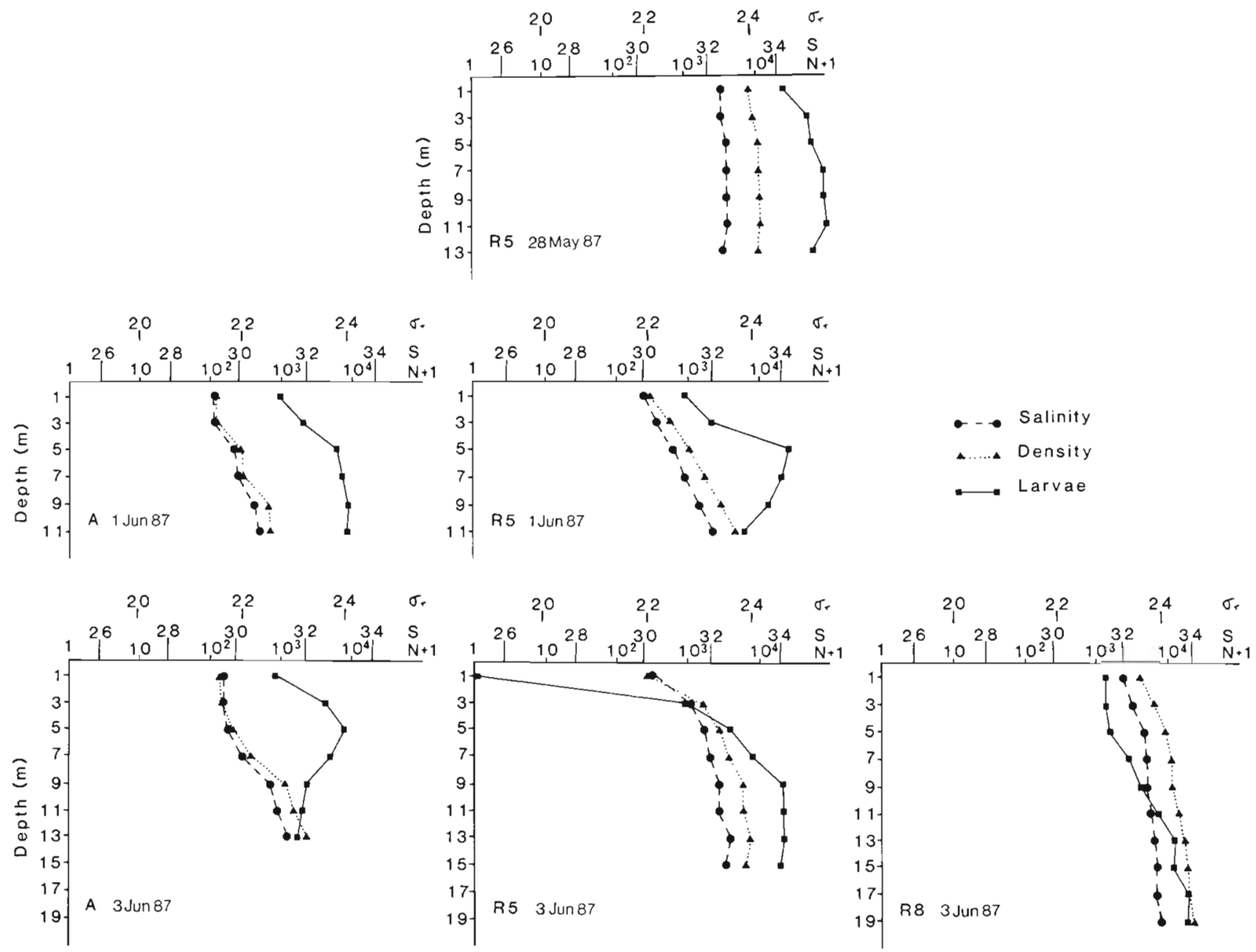

Fig. 4. Owenia fusiformis. Profiles of salinity $(S)$, density $\left(\sigma_{T}\right)$ and larval concentration $\left(m^{-3}\right)(N+1)$, at $S t n s ~ A, R_{5} \& R_{8}(28 M a y$, 1 \& 3 June 1987) 
Table 1. Mean, maximum and minimum values of physical gradients between surface and bottom (temperature, salinity and density differences) at Stns $A, R_{5} \& R_{8}$ during the cruise from 16 May to 3 June 1987

\begin{tabular}{|c|c|c|c|c|c|c|c|c|c|}
\hline \multirow[t]{2}{*}{ Station } & \multicolumn{3}{|c|}{ Temperature difference $\left({ }^{\circ} \mathrm{C}\right)$} & \multicolumn{3}{|c|}{ Salinity difference } & \multicolumn{3}{|c|}{ Density difference $\left(\sigma_{t}\right)$} \\
\hline & Mean & Min & $\operatorname{Max}$ & Mean & Min & $\operatorname{Max}$ & Mean & Min & $\operatorname{Max}$ \\
\hline A & 1.0 & 0.7 & 1.6 & 2.4 & 1.2 & 5.5 & 2.01 & 1.04 & 4.41 \\
\hline $\mathrm{R}_{5}$ & 1.1 & 0.3 & 1.9 & 1.6 & 0.1 & 3.3 & 1.39 & 0.16 & 2.73 \\
\hline $\mathrm{R}_{8}$ & 0.7 & 0.1 & 1.9 & 1.4 & 0.5 & 3.2 & 1.15 & 0.37 & 2.74 \\
\hline
\end{tabular}

surface and bottom layers were $2.0^{\circ} \mathrm{C}$ for temperature, 5.50 for salinity and 4.50 for density. Within each station (Table 1), the variation of vertical stratification was due to turbulence from wind and tide and/or tidal stream transport.

During the cruises, surface and bottom water temperatures increased. This rise was more important at the surface than at the bottom and increased the vertical temperature gradient. Moreover, temperature tended to decrease in a downstream direction in relation to a decrease of the influence of Seine freshwater.

\section{Changes of larval population}

The changes of frequencies of the 4 planktonic stages between 16 May and 9 June 1987 at $\operatorname{Stn} R_{5}$ showed that only 1 larval cohort was present during the cruise. We observed a succession of the 4 stages without massive appearance of new Stage 1 larvae (Fig. 5). Stage 1 was dominant on 16 May and decreased suddenly on 18 May. Nevertheless, some Stage 1 persisted until 3 June. Stage 2 became dominant on 18 May, and persisted in abundance (90 to $100 \%$ of the population) until the end of May. It then decreased at the begin-

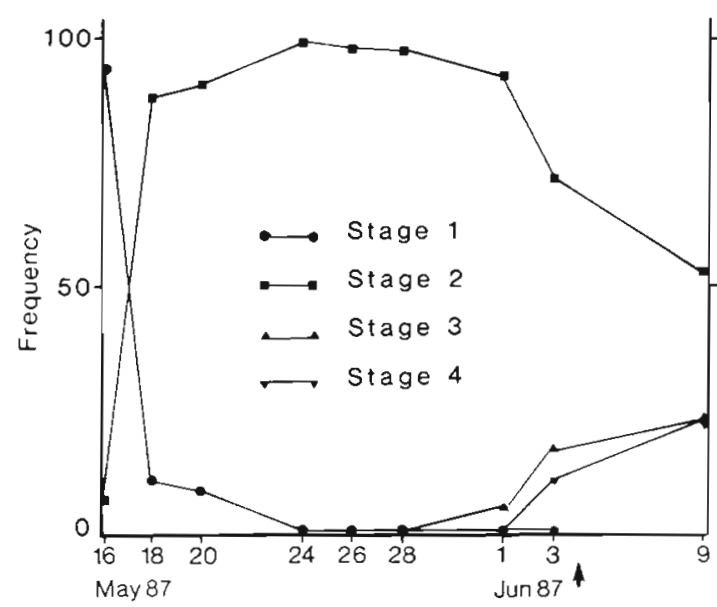

Fig. 5. Owenia fusiformis. Temporal changes of relative frequencies of the 4 planktonic stages between 16 May and 9 June 1987 at Stn $R_{5}$. Arrow: beginning of settlement ning of June. Stage 3 appeared on 28 May and Stage 4 appeared on 1 June.

Given their morphology (Wilson 1932), the majority of larvae present on 16 May would be expected to be 3 or 4 d old. Although some larvae (Stage 1) were already observed on 9 May at Stns I, D \& C, the main spawning probably occurred around 12 May.

A drastic reduction in larval density was seen on 3 and 9 June (from 11000 to 35 larvae $\mathrm{m}^{-3}$ ) concomitant with the mass settlement which took place between 3 and 9 June (Dauvin in press). Therefore, between spawning and settlement, the duration of larvai life could be estimated to be about 1 mo.

\section{Larval vertical distribution}

From 9 May to 3 June 1987, depth-averaged concentrations of Owenia fusiformis larvae were $13617 \pm$ $15193 \mathrm{~m}^{-3}$ and varied between $161 \pm 160 \mathrm{~m}^{-3}$ at Stn I on 9 May and $69787 \pm 25469 \mathrm{~m}^{-3}$ at $S t n R_{5}$ on 28 May. The concentrations reached 100016 larvae $\mathrm{m}^{-3}$ at $\mathrm{Stn}$ $\mathrm{R}_{5}$ (11 m deep) on 28 May. The coefficient of variation (CV) among profiles ranged from $22.8 \%$ at $S \operatorname{tn} R_{8}$ on 18 May to $123.4 \%$ at Stn A on 20 May.

Owenia fusiformis larvae were well-mixed over the water column when stratification was low: e.g. Stn $R_{5}$ on 16 May, Stn $R_{8}$ on 18 May and $\operatorname{Stn} R_{5}$ on 28 May (Figs. 2, 3 \& 4). Larvae were aggregated within subsurface depth intervals when stratification was pronounced. Two types of profiles were observed: (1) larvae were most concentrated between 3 and $5 \mathrm{~m}$ with sharply reduced concentrations under $5 \mathrm{~m}$ : e.g. Stn A on 20 May (Fig. 3). (2) larvae occurred with almost constant concentrations: e.g. Stn $R_{8}$ on 18 May (Fig. 3). The ZCM of $O$. fusiformis larvae was $8.20 \pm 2.36 \mathrm{~m}$ from the surface, varying from $4.47 \mathrm{~m}$ at Stn A on 26 May to $14.50 \mathrm{~m}$ at $\mathrm{Stn} \mathrm{R}_{8}$ on 3 June.

\section{Ontogenic vertical migration}

Mean values of ZCMs were $6.54 \pm 2.70 \mathrm{~m}$ from the surface for Stage 1, $8.26 \pm 2.68 \mathrm{~m}$ for Stage 2, $9.92 \pm$ 

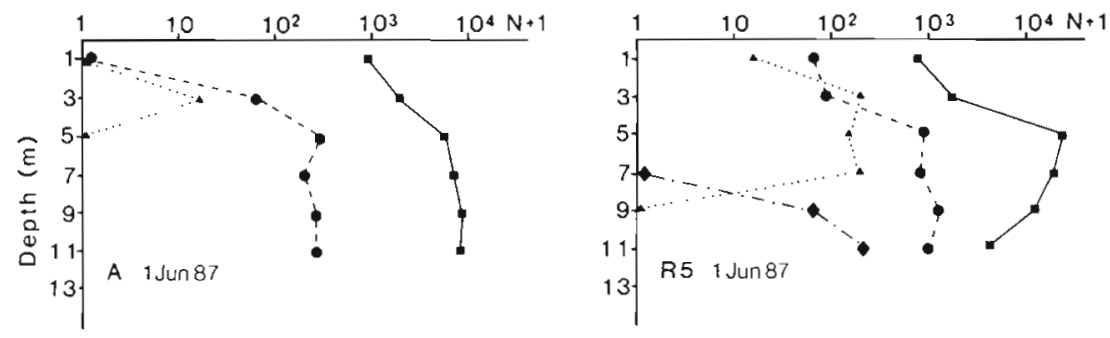

Fig. 6. Owenia fusiformis. Vertical distribution of the 4 planktonic stages at Stns $A \& R_{5}(1 \& 3$ June 1987). Density $(\mathrm{N}+1)=$ number of larvae $\mathrm{m}^{-3}$
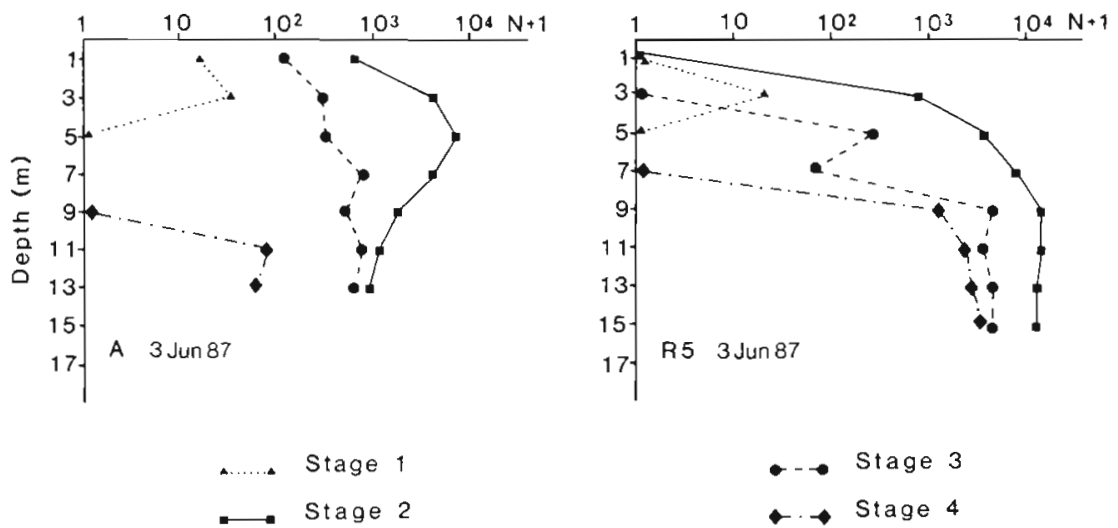

$2.85 \mathrm{~m}$ for Stage 3 and $12.59 \pm 2.49 \mathrm{~m}$ for Stage 4. There were significant differences within these ZCMs (Kruskal-Wallis test, $\mathrm{H}=17.47, \mathrm{p}<0.001$ ). Differences in vertical distribution for each stage were also observed from data collected $1 \& 3$ June at Stns A \& $R_{5}$ (Fig. 6) where Stage 1 larvae were preferentially near the surface and, conversely, Stage 4 were limited to the deeper layer. The normalization of depth for all sam-
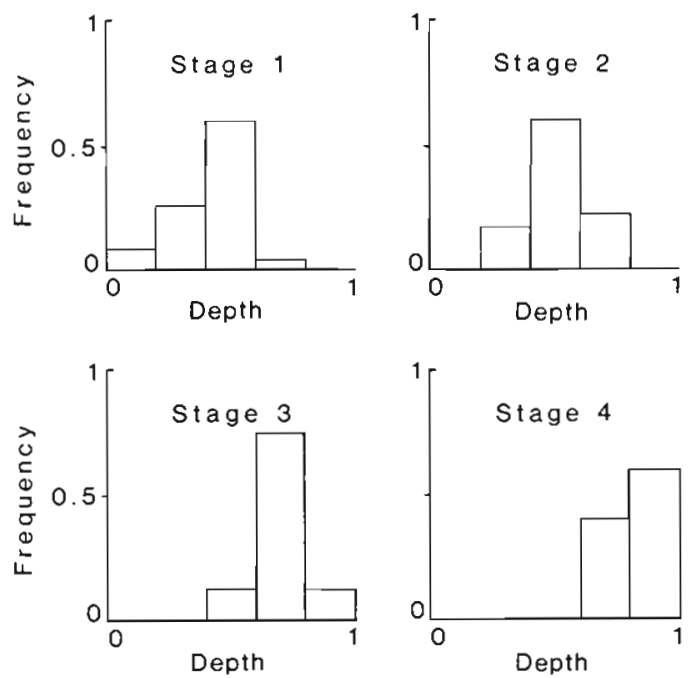

Fig. 7. Owenia fusiformis. Frequency of vertical distribution of larval center of mass (ZCM) for each stage (stations sampled between 9 May to 3 June 1987) after normalization of depth from 0 (surface) to 1 (bottom) and dividing the total column water into 5 equal sections pled stations from 0 (surface) to 1 (bottom) showed that (1) Stage 1 larvae were situated preferentially within the upper 0.2 to 0.6 of water column, (2) Stage 2 larvae within the upper 0.2 to 0.8 , (3) Stage 3 larvae within the upper 0.6 to 0.8 and (4) Stage 4 larvae within the upper 0.6 to 1 (Fig. 7). These results showed that Owenia fusiformis larvae exhibited an ontogenetic migration.

The ZCMs of the 4 larval stages were under the pycnocline with the exception of Stage 1 on $1 \& 3$ June at $\operatorname{Stn} A$ and 28 May at Stn $R_{5}$, and Stage 2 on 3 June at Stn A (Fig. 8). Calculations of Spearman rank correlation coefficients showed that the ZCMs were correlated with the depth where the seaward residual flow is null,

Table 2. Owenia fusiformis. Spearman rank correlation coefficients for larval center of mass (ZCM) of different larval stages versus $z_{u=0}$ and for CVs of different larval stages versus $\hat{S}$. For each coefficient, the number of data $n$ is given in brackets. $z_{u=0}$ : depth where seaward flow was null; CV: coefficient of variation of larval concentration; $S$ : index of stratification

\begin{tabular}{|c|c|c|c|c|}
\hline & $Z_{C} M_{1}$ & $\mathrm{ZCM}_{2}$ & $\mathrm{ZCM}_{3}$ & $\mathrm{ZCM}_{4}$ \\
\hline \multirow[t]{2}{*}{$z_{u=0}$} & $\begin{array}{l}(\mathrm{n}=20) \\
0.646^{\circ}\end{array}$ & $\begin{array}{l}(\mathrm{n}=22) \\
0.671 \cdots\end{array}$ & $\begin{array}{c}(\mathrm{n}=8) \\
0.583\end{array}$ & $\begin{array}{l}(\mathrm{n}=5) \\
0.900^{\circ}\end{array}$ \\
\hline & $C V_{\mathrm{I}}$ & $\mathrm{CV}_{2}$ & $\mathrm{CV}_{3}$ & $\mathrm{CV}_{4}$ \\
\hline$S$ & $\begin{array}{c}(n=20) \\
0.502^{\circ}\end{array}$ & $\begin{array}{c}(n=20) \\
0.666^{\cdots}\end{array}$ & $\begin{array}{c}(\mathrm{n}=8) \\
0.333\end{array}$ & $\begin{array}{c}(\mathrm{n}=5) \\
-0.300\end{array}$ \\
\hline$p<0.0$ & - $p<0.0$ & $\cdots p<$ & 01 (Sche & r 1984) \\
\hline
\end{tabular}




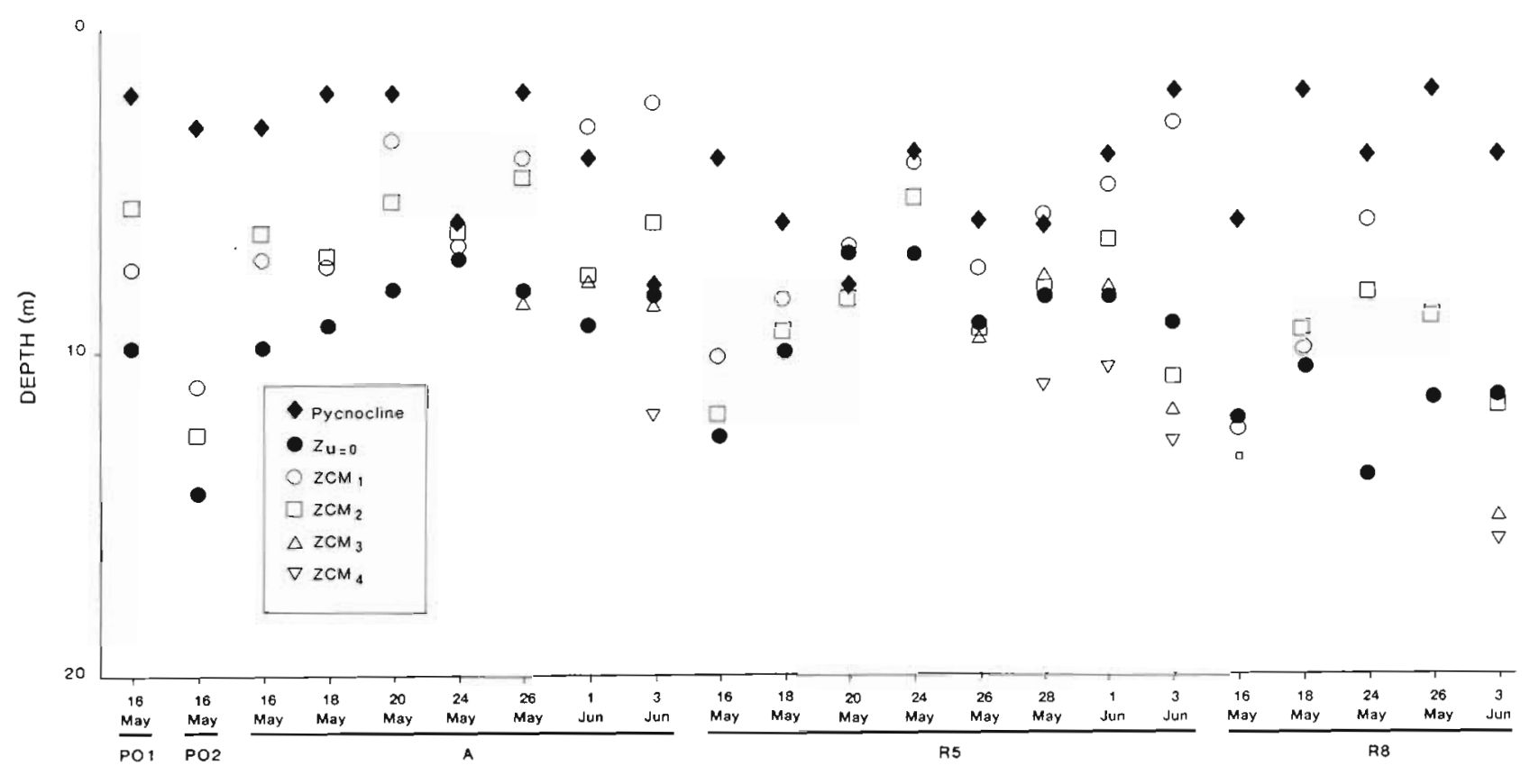

STATION/PROFILE

Fig. 8. Owenia fusiformis. Vertical location of larval center of mass (ZCM) for Stages 1 to 4 , pycnocline and depth where the seaward residual flow was null $\left(z_{1}=0\right)$. Only stations sampled between 16 May and 3 June were considered

$z_{u=0}$, for Stages 1, $2 \& 4$ (Table 2). Except for 1 case, on 16 May at Stn $R_{8}$, the $Z^{2 C M}$ was always above $z_{u=0}$ between 0.1 and $7.8 \mathrm{~m}$ with a mean value of $3.0 \mathrm{~m}$ (Fig. 8). For Stage 2, the $\mathrm{ZCM}_{2}$ was located preferentially slightly above $z_{u=0}$ between 0.1 and $5.9 \mathrm{~m}$ with a mean value of $1.4 \mathrm{~m}$. It was under $z_{u=0}$ only in 5 cases: on 20 \& 26 May ands 3 June at $\operatorname{Stn} R_{5}$ and on 16 May \& 3 June at $\operatorname{Stn} \mathrm{R}_{8}$ (Fig. 8). The $\mathrm{ZCM}_{3}$ was situated on each side of $z_{u=0}$ between 1.5 and $-4.6 \mathrm{~m}$ with a mean value of $-1.0 \mathrm{~m}$ (Fig. 8). The $\mathrm{ZCM}_{4}$ occurred well under $z_{u=0}$ between -2.5 and $-5.2 \mathrm{~m}$ with a mean value of $-3.6 \mathrm{~m}$ (Fig. 8).

Moreover, water column stratification affected the vertical distribution of different larval stages in different ways. For Stages 1 \& 2, the coefficient of variation (CV) in larval vertical distribution increased with the stratification index (S) (Fig. 9): the correlation between $\mathrm{CV}$ and $\hat{S}$ for both stages was significant (Table 2). Conversely, no significant correlation was found between CV and $S$ for Stages 3 \& 4 (Table 2). Regardless of the degree of stratification, Stages $3 \& 4$ larvae stayed preferentially in the lower part of the water column.

\section{DISCUSSION}

During cruises between 9 May \& 9 June 1987 , only 1 massive larval cohort was identified with important densities. The principal spawning date was estimated to be around 12 May. However, the presence of young larvae (Stage 1) from 9 May to 1 June confirmed the results of Gentil et al. 1990 showing that spawning is not perfectly synchronized for all Owenia fusiformis females. The duration of larval life was estimated to be ca $1 \mathrm{mo}$, similar to results obtained in cultures by Wilson (1932). Four larval stages were distinguished in relation to the morphology.

Owenia fusiformis larvae were generally located under the pycnocline. However, the stratification of the water column could interfere with larval vertical distribution. For a low index of stratification $(\hat{S}<0.1)$, Stages 1 \& 2 larvae were distributed evenly over the whole water column, probably in relation to an increase of turbulence associated with weak stratification. In this case, these larvae can be considered as passive particles unable to form aggregations. However, a stronger stratification $(\hat{S}>0.1)$ generated subsurface aggregations of these larvae under the pycnocline. O. fusiformis larvae of Stages 1 \& 2 seemed to be able to partially control their vertical distribution if turbulence was not high. This has also been observed for Placopecten magellanicus larvae on Georges Bank, NW Atlantic (Tremblay \& Sinclair 1990). On the other hand, Stages $3 \& 4$ larvae were always located in the lower part of the water column and seemed to be able to oppose turbulent action, whatever its intensity. Unfortunately, we have limited data for these 2 stages 


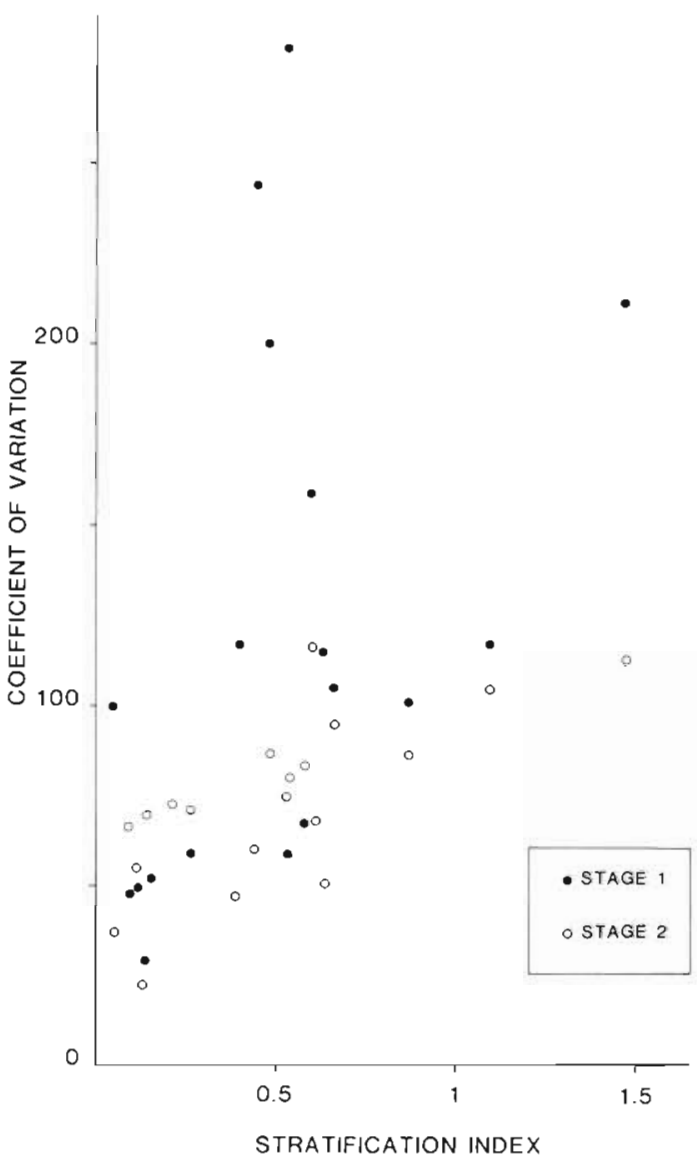

Fig. 9. Owenia fusiformis. Coefficient of variation (CV) in larval vertical distribution versus index of water column stratification $(\hat{S})$ for Stages 1 \& 2 larvae. Only stations sampled between 16 May and 3 June were considered

where there was a low index of stratificaton (except on 28 May at $\mathrm{Stn} \mathrm{R}_{5}$ for Stage 3 larvae).

Salomon (1986) described residual circulation outside the estuary in relation to horizontal gradients of density. He showed the formation of an Ekman's spiral such that the diluted surface layer is characterized by a net seaward residual flow and the deeper saline layer exhibits a landward residual flow. The average velocity of the net seaward residual flow can reach $5 \mathrm{~cm} \mathrm{~s}^{-1}$ in surface waters (Le Hir et al. 1986) while the velocity of the landward residual flow varies between 2 and $5 \mathrm{~cm}$ $\mathrm{s}^{-1}$ near the bottom (Le Hir \& L'Yavanc 1986). When the seaward residual flow was weak around middepth, a slow current was generated perpendicular to the estuary with a speed of $1 \mathrm{~cm} \mathrm{~s}^{-1}$ (Salomon 1986).

The ZCMs of the different larval stages varied from $6.54 \mathrm{~m}$ for Stage 1 to $12.59 \mathrm{~m}$ for Stage 4 , showing an ontogenic migration. Stage 1 larvae with a life duration of about $6 \mathrm{~d}$ were principally located in the diluted surface layer and were carried downstream. The 3 following stages occurred at progressively deeper mean depths. Stage 2 larvae, which correspond to the major part of Owenia fusiformis larval life (15 d), were located just above $z_{u}=0$. Therefore, this subsurface aggregation of Stage 2 larvae could confer advantages with respect to larval retention abilities by limiting transport of this stage in an offshore direction by surface currents and favouring a slight transport perpendicular to the estuary. Such distribution of Stage 2 larvae was observed in the retention of Rhithropanopeus harrisil crab larvae in the Newport River estuary, (North Carolina, USA) (Cronin 1982). This subsurface location of Stages 1 \& 2 larvae limits wind action on larval dispersal insofar as this action principally concerns surface waters. Strong winds $\left(15 \mathrm{~m} \mathrm{~s}^{-1}\right)$ can generate a residual circulation in surface waters varying between 10 and $30 \mathrm{~cm} \mathrm{~s}^{-1}$ (Le Hir et al. 1986). Stages $3 \& 4$, with a duration of life of $7 \mathrm{~d}$ and 1 or $2 \mathrm{~d}$ respectively, had ZCMs below the level of no net motion and, consequently, were transported upstream returning to the area of the adult population

Therefore, this ontogenic migration in a partially wellmixed estuary with a 2-layer circulation favours larval retention as Bousfield (1955) showed in an early work on Bálanus improvisus barnacle larvae near the head of the Miramichi Estuary, (New Brunswick, Canada). The role of a 2-layer circulation in retention processes was also shown for phytoplankton. In Chesapeake Bay, USA, during early spring, the dinoflagellate Prorocentrum mariae-lebouriae is accumulated under a stable pycnocline in northward-flowing bottom waters and is transported from the mouth to the upper bay, a distance of $240 \mathrm{~km}$. During summer and autumn, after a bloom in surface waters, Prorocentrum is transported to the mouth of the bay where it returns to bottom waters (Tyler \& Seliger 1978, Seliger et al. 1979).

However, the eastern part of the Bay of Seine opens to the English Channel and physical data showed that the influence of Seine freshwater decreased rapidly from upstream to downstream. Therefore, ontogenic migration could favour larval retention only if larvae were not transported too far offshore and could benefit from the 2-layer circulation. The influence of Seine freshwater was estimated to extend around $15 \mathrm{n}$ miles from the mouth of the bay (C.O.B. 1978).

Two hypotheses could explain this ontogenic migration: (1) alterations of larval morphology and density generating a change in larval buoyancy and (2) modifications of swimming behaviour in response to environmental factors such as gravity or light. Current information does not allow us to argue for or against either of these 2 hypotheses.

Ontogenic migration is not a general feature in polychaete larvae. Banse (1986) and Levin (1986) did not observe changes in the vertical distribution of planktonic larvae of some Spionidae species in the Kiel Bay, Germany and Mission Bay, California, USA, respectively. However, another study dealing with the 
polychaete Pectinaria koreni's larval distribution in the eastern part of the Bay of Seine (Lagadeuc 1990. Lagadeuc et al. 1990), has also shown the importance of ontogenic migration in relation to estuarine circulation and responses to low salinities in larval retention.

In conclusion, most studies on polychaete larvae made in the laboratory or in the field assume that they were passive within the water column like inert particles (Hannan 1984, Banse 1986, Levin 1986). This study shows that Owenia fusiformis larvae, like some other species such as Phyllodoce mucosa in the Bay of Arcachon, (Biscaye Bay, France) (Mathivat-Lallier \& Cazaux 1990) and Pectinaria koreni in the Bay of Seine (Lagadeuc 1990), are able to partially control their vertical distribution. The vertical distribution of $O$. fusiformis larvae might well result from interactions between behavioral patterns and physical processes like water column stratification according to turbulence. This study confirms the existence of retention structure of polychaete larvae in estuarine and coastal waters although their swimming capacity is often limited (Stancyk \& Feller 1986). Two processes appear to be essential in our case: (1) ontogenic migration allowing a return of older larvae to adult area and (2) the location of Stage 2 larvae just above the depth where the longitudinal seaward flow is null, thus limiting the transport of these larvae in the downstream direction. Therefore, this retention should limit larval transport out of the eastern part of the Bay of Seine and favours recruitment of larvae to the adult site. In this manner, it can partly explain the spatio-temporal stability of the $O$. fusiformis population in this zone (Dauvin \& Gillet 1991) assuming that horizontal transport of the first stages is not important.

Acknowledgements. This study forms a part of the contribution of the GDR Manche under the 'Programme National sur le Déterminisme du Recrutement of the Centre National de la Recherche Scientifique. The authors thank the crews of NO 'Pluteus II' and 'Côte de Normandie', and J.C. Lorgeré for their valuable assistance in field work, C. Le Roux and J. L. Douvillé for help in computer analysis, L. Cabioch and C. Retière for their advice during this work, E. O'Ceidigh for help in correcting the English text, and 3 anonymous reviewers for their detailed and very useful comments on the first draft.

\section{LITERATURE CITED}

Banse, K. (1986). Vertical distribution and horizontal transport of planktonic larvae of Echinoderms and benthic Polychaetes in an open coastal sea. Bull. mar. Sci. 39: 162-175

Bousfield, E. L. (1955). Ecological control of the occurrence of barnacles in the Miramichi Estuary. Bull. nat. Mus. Can. 137: $1-69$

Cabiorh. L. (ed.) (1986). La Baie de Seine. Colloque National du CNRS, Caen, 1985, Actes Collog. IFREMER 4: 1-531

Cabioch, L., Dauvin, J. C., Retière, C., Rivain, V., Archam- bault, D. (1982). Evolution de peuplements benthiques des fonds sédimentaires de la région de Roscoff, perturbés par les hydrocarbures de I'Amoco Cadiz. Neth. J. Sea Res. 16: 491-501

Cabioch, L., Gentil, F. (1975). Distribution des peuplements benthiques dans la partie orientale de la Baie de Seine. C. r. Acad. Sci., Paris 280D: 571-574

Cameron, R. A. (1986). Introduction to the invertebrate larval biology workshop: a brief background Bull. mar. Sci. 39: 145-161

Chabert d'Hières, G. (1986). La circulation des eaux en Baie de Seine. Actes Colloq. IFREMER 4: 15-23

C.O.B. (1978). Baie de Seine, Campagne Thalia mai 1978, Présentation des résultats. CNEXO-COB Département Environnement littoral, Centre IFREMER Brest, BP 70 . 29263 Plouzané, France

Cronin, T W (1982). Estuarine retention of larvae of the crab Rhithropanopeus harrisii. Estuar. coast. Shelf Sci. 17: 207-220

Cronin, T. W. Forward, R. B. (1986). Vertical migration cycles of crab larvae and their role in larval dispersal. Bull. mar Sci. 39: 192-201

Dauvin, J. C. (in press). Cinétique du recrutement et croissance des juveniles d'Owenia fusiformis en Baie de Seine (Manche orientale). Oceanol. Acta

Dauvin, J. C., Gillet, P. (1991). Spatio-temporal variability of the demographic structure of Owenia fusiformis Delle Chiaje (Annelida: Polychaeta) from the Bay of Seine (eastern English Channel). J. exp. mar. Biol. Ecol. 152: 105-122

De Wolf, P. (1974). On the retention of marine larvae in estuaries. Thalassia Jugosi. 10: 415-424

Epifanio, C. E., Masse, A. K., Garvine, R. W. (1989). Transport of blue crab larvae by surface currents off Delaware Bay, USA. Mar. Ecol. Prog. Ser. 54: 35-41

Fortier, L., Leggett, W C. (1982). Fickian transport and the dispersal of fish larvae in estuaries. Can. J. Fish. Aquat. Sci. 39: 1150-1163

Frontier, S. (1969). Sur une méthode d'analyse faunistique rapide du zooplancton. J. exp. mar. Biol. Ecol. 3: 18-26

Frontier, S. (1972). Calcul de l'erreur sur un comptage de zooplancton. J. exp mar Biol. Ecol. 10: 121-132

Gentil, F. (1976). Distribution des peuplements benthiques en Baie de Seine. Thèse de $3^{\text {eme }}$ cycle. Univ. Paris

Gentil, F., Dauvin, J. C., Ménard, F. (1990). Reproductive biology of the Polychaete Owenia fusiformis Delle Chiaje in the Bay of Seine (eastern English Channel). J. exp. mar. Biol. Ecol. 142: 13-23

Gentil, F., Irlinger, J. P., Elkaïm, B., Proniewsky, F. (1986). Premières données sur la dynamique du peuplement macrobenthique des sables fins envasés à Abra alba de la Baie de Seine orientale. Actes Colloq. IFREMER 4: $409-420$

Hannan, C. A. (1984). Planktonic larvae may act like passive particles in turbulent near-bottom flows. Limnol. Oceanogr 29: 1108-1116

Lagadeuc, Y (1990). Processus hydrodynamiques, dispersion larvaire et recrutement en régime mégatidal. Exemple de Pectinaria koreni (Annélide Polychète) en Baie de Seine (Manche). Thèse d'Lniversité, Lille

Lagadeuc, Y., Conti, P., Retière, C., Cabioch, L., Dauvin, J. C. (1990). Processus hydrodynamiques et recrutement de Pectinaria koreni, Annélide Polychète à cycle benthopélagique, en Bare de Seine orientale. Océanis, Paris 16 : 245-256

Le Hir, P., L'Yavanc, J. (1986). Observations de courant en Baie de Seine. Actes Colloq. IFREMER 4: 25-33

Le Hir, P., Salomon, J. C., Le Provost, C., Chabert d'Hyères, 
G., Mauvais, J. L. (1986). Approche de la circulation résiduelle en Baie de Seine. Actes Colloq. IFREMER 4: $63-72$

Levin, L. A. (1986). The influence of tides on larval availability in shallow waters overlying a mudflat. Bull. mar Sci. 39: $224-233$

Mathivat-Lallier, M. H., Cazaux, C. (1990). Larval exchange and dispersion of polychaetes between a bay and the ocean. J. Plankton. Res. 12: 1163-1172

Salomon. J. C. (1986). Courantologie calculée en Baie de Seine. Actes Colloq. IFREMER 4: 35-42

Scheltema, R. S. (1986). On dispersal and planktonic larvae of benthic invertebrates: an eclectic overview and summary of problems. Bull mar Sci. 39: 290-322

Scherrer, B. (1984). Biostatistique. Ed. Gaëtan Morin, Paris

Seliger, H. H., Tyler, M. A., McKinley, K. R. (1979). Phytoplankton distributions and red tides resulting from frontal circulation patterns. In: Taylor, D. L., Seliger, H. H. (eds.)

This article was submitted to the editor
Proc. 2nd int. Conf. on Toxic Dinoflag. Blooms. Key Biscayne, USA, p. 239-248

Stancyck, S. E., Feller, R. J. (1986). Transport of non-decapod invertebrate larvae in estuaries: an overview. Bull. mar Sci. 39: 257-268

Sulkin, S. D. (1984). Behavioral basis of depth regulation of the larvae of brachyuran crabs. Mar Ecol. Prog. Ser 15: 181-205

Tremblay, M. J., Sinclair, M. (1990). Sea scallop larvae Placopecten magellanicus on Georges Bank: vertical distribution in relation to water column stratification and food. Mar Ecol. Prog. Ser 61. 1-15

Tyler, M. A., Seliger, H. H. (1978). Annual subsurface transport of a red tide dinoflagellate to its bloom area: water circulation patterns and organism distribution in the Chesapeake Bay. Limnol. Oceanogr. 23: 227-246

Wilson, D. P. (1932). On the mitraria larvae of Owenia fusiformis Delle Chiaje. Phil. Trans. R. Soc. 221: 231-334

Manuscript first received: July 4, 1991

Revised version accepted: December 30, 1991 